\title{
PNGARUH PENEMPATAN KERJA, KEAHLIAN ( SKILL ) DAN KEPUASAN KERJA TERHADAP PENINGKATAN KINERJA KARYAWAN PADA PT. OSI ELECTRONICS BATAM
}

\author{
Mira Yona \\ Program Studi Manajemen, Fakultas Ekonomi, Universitas Riau Kepulauan \\ mirayona@yahoo.co.id
}

\begin{abstract}
ABSTRAK
Penelitian ini bertujuan untuk mengetahui pengaruh penempatan kerja terhadap peningkatan kinerja karyawan, pengaruh keahlian (skill) terhadap peningkatan kinerja karyawan, pengaruh kepuasan kerja terhadap peningkatan kinerja karyawan, pengaruh penempatan kerja,keahlian (skill), dan kepuasan kerja secara bersama - sama terhadap peningkatan kinerja karyawan. Penelitian ini termasuk jenis penelitian deskriptif kuantitatif dengan pengujian hipotesis. Populasi dalam penelitian ini adalah sampel dari populasi karyawan bagian PT. Osi Electronics Batam, yang berjumlah 95 orang dengan teknik sampel acak sederhana (random sampling). Teknik pengumpulan data menggunakan kuesioner dan diuji validitas serta reliabilitasnya. Teknik analisis data yang digunakan adalah uji $F$, uji $t$ serta uji $(R)^{2}$ Hasil perhitungan statistic menunjukan nilai $F$ hitung sebesar $124.188>F$ table 3,10 dengan tingkat signifikan 0,000 lebih kecil dari 0.05 maka kesimpulannya Ha diterima, Ho ditolak yaitu secara bersamasama antara variable Penempatan Kerja,Keahlian (Skill) dan Kepuasan Kerja terdapat pengaruh yang positif dan signifikan terhadap variable Peningkatan Kinerja. Hasil penelitian ini menunjukkan bahwa penempatan kerja, keahlian (slill) dan kepuasan kerja secara bersama-sama mempunyai pengaruh yang signifikan terhadap peningkatan kinerja kayawan. Sehingga untuk meningkatkan kinerja karyawan PT. Osi Electronics Batam harus memberikan penempatan kerja, keahlian (slill) dan kepuasan kerja secara bersama-sama sehingga kinerja kayawan akan meningkat.
\end{abstract}

\section{Kata Kunci : Penempatan Kerja, Keahlian (Skill), Kepuasan Kerja,} Peningkatan Kinerja Karyawan

\section{PENDAHULUAN}

Pengelolaan terhadap sumber daya manusia merupakan hal yang penting dalam pencapaian tujuan. Umumnya pimpinan perusahaan mengharapkan kinerja yang baik dari masing-masing karyawan dalam mengerjakan tugas-tugas yang diberikan sebuah perusahaan. Perusahaan menyadari bahwa sumber daya manusia merupakan modal dasar dalam proses pembangunan perusahaan bahkan nasional, oleh karena itu kualitas sumber daya manusia senantiasa harus dikembangkan dan diarahkan agar tercapainya tujuan yang telah ditetapkan oleh suatu perusahaan atau organisasi.

PT.Osi Electronics Batam adalah sebuah perusahaan yang 
bergerak di bidang electronics yaitu memproduksi PCBA dan membuat LCD PT. Osi Electronics Batam ditempat di Cammo Industrial Park, Blok F No.3A Batam Centre.Merinci mengenai keinginan-keinginan karyawan antara lain; upah, keterjaminan pekerjaan, teman-teman kerja yang menyenangkan, penghargaan atas pekerjaan yang dilakukan, pekerjaan yang berarti, kesempatan untuk maju, kondisi kerja yang nyaman, aman dan menarik, kepemimpinan yang mampu dan adil, perintah dan arahan yang masuk akal dan suatu organisasi yang relevan secara sosial.

Dan sedikit untuk mengetahui kepuasan kerja yang merupakan hal yang bersifat individu dan memiliki tingkat kepuasan yang berbeda-beda, salah satu definisi kepuasan kerja adalah "suatu sikap yang umum sebagai hasil dari berbagai sifat khusus individu terhadap faktor kerja, karakteristik individu dan hubungan sosial individu di luar pekerjaan itu sendiri".Dan faktor-faktor yang mempengaruhi kepuasan kerja antara lain; faktor kepuasan finansial, faktor kepuasan fisik, faktor kepuasan sosial, dan faktor kepuasan psikologi

Peningkatan kinerja karyawan akan membawa kemajuan bagi perusahaan untuk dapat bertahan dalam suatu persaingan lingkungan bisnis yang tidak stabil. Oleh karena itu upaya-upaya untuk meningkatkan kinerja karyawan merupakan tantangan manajemen yang paling serius karena keberhasilan untuk mencapai tujuan dan kelangsungan hidup perusahaan tergantung pada kulitas kinerja sumber daya manusia yang ada di dalamnya.

Oleh karena, itu salah satu cara terbaik untuk meningkatkan kinerja karyawan adalah dengan menghubungkan penempatan kerja, keahlian (skill) dan kepuasan kerja.

Bagi perusahaan, penelitian kinerja sangat berguna untuk menilai kuantitas, kualitas, efisiensi perubahan, motivasi para karyawan serta melakukan pengawasan dan perbaikan.Kinerja karyawan yang optimal sangat dibutuhkan untuk meningkatkan produktivitas dan menjaga kelangsungan perusahaan.

Berangkat dari kondisi tersebut, maka dijadikan dasar untuk melaksanakan penelitian tentang peningkatan kinerja karyawan. Berdasarkan uraian di atas, maka penullis memberi judul penelitian :"Pengaruh Penempatan Kerja, Keahlian (Skill) Dan Kepuasan Kerja Terhadap Peningkatan Kinerja Karyawan Pada PT. Osi Electronics Batam".

\section{Rumusan Masalah Penelitian}

1. Bagaimana pengaruh penempatan kerja terhadap peningkatan kinerja karyawan PT. Osi Electronics Batam?

2. Bagaimana pengaruh keahlian (skill) terhadap peningkatan kinerja karyawan PT. Osi Electronics Batam?

3. Bagaimana pengaruh kepuasan kerja terhadap peningkatan kinerja karyawan PT. Osi Electronics Batam?

4. Bagaimana pengaruh penempatan kerja,keahlian (skill), dan kepuasan kerja secara bersama-sama terhadap peningkatan kinerja karyawan PT. Osi Electronics Batam?

\section{Tujuan Penelitian}

1. Untuk mengetahui bagaimana pengaruh penempatan kerja terhadap peningkatan kinerja karyawan PT. Osi Electronics Batam. 
2. Untuk mengetahui bagaimana pengaruh keahlian (skill) terhadap peningkatan kinerja karyawan PT. Osi Electronics Batam.

3. Untuk mengetahui bagaimana pengaruh kepuasan kerja terhadap peningkatan kinerja karyawan PT. Osi Electronics Batam.

4. Untuk mengetahui bagaimana pengaruh penempatan kerja,keahlian (skill), dan kepuasan kerja secara bersama - sama terhadap peningkatan kinerja karyawan PT. Osi Electronics Batam.

\section{Manfaat Penelitian}

Bagi Perusahaan

Dari hasil penelitian diharapkan dapat menjadi bahan untuk pertimbangan dalam penentuan langkah yang akan ditempuh oleh perusahaan dalam rangka peningkatan kinerja karyawan.

\section{Bagi Pembaca}

Penelitian ini diharapkan dapat memberikan informasi dan referensi bagi pihak-pihak yang berkepentingan terutama yang berkaitan dengan penempatan kerja, keahlian ( skill), kepuasan kerja dan peningkatan kinerja karyawan.

\section{Pengertian Penempatan Kerja}

Penempatan pegawai adalah tindak lanjut dari seleksi, yaitu menempatkan calon pegawai yang diterima pada jabatan/pekerjaan yang dibutuhkannya dan sekaligus mendelegasikan authority kepada orang tersebut".

Sedangkan, Menurut Veithzal Rivai dan Ella jauvani sagala (2009:198) "Penempatan adalah penugasan kembali seorang pegawai kepada pekerjaan barunya.
Sedarmayanti (2009:56) sebagai berikut: penempatan pegawai dari dalam dan orientasi/pelatihan pegawai dipusatkan pada pengembangan pegawai, mereka harus memelihara keseimbangan antara perhatian organisasi terhadap efesiensi (kesesuaian optimal antara skill dan tuntutan) dengan keadilan (mempersepsi bahwa kegiatan tersebut adalah adil, sah dan memberikan kesempatan merata).

Sedangkan menurut Tohardi (2006:220) penempatan adalah suatu proses mengetahui karakter atau syaratsyarat yang diperlukan untuk mengerjakan suatu pekerjaan /tugas selanjutnya menjadi orang (pekerja/pegawai) yang cocok dengan pekerjaan yang ada.

Menurut Sunyoto (2012:122), penempatan merupakan "proses atau pengisian jabatan atau penugasan kembali pegawai pada tugas atau jabatan baru atau jabatan yang berbeda". Sedangkan menurut Yani (2012:74), placement ataupenempatan adalah "penunjukkan kepada karyawan untuk menduduki atau melakukan pekerjaan baru".

Berdasarkan definisi yang yang dikemukakan oleh para ahli tersebut, maka dapat disimpulkan bahwa penempatan adalah kebijaksanaan sumber daya manusia untuk menetukan posisi/ jabatan seseorang.Berhubungan dengan penilaian kinerja, faktor kinerja merupakan masalah lain yang timbul pada kalangan pekerja atau pegawai.

\section{Pengertian Keahlian (Skill)}

Keahlian merupakan sesuatu minat atau bakat yang harus dimiliki oleh seseorang, dengan keahlian yang dimilikinya memungkinkan untuk dapat menjalankan dan menyelesaikan tugas-tugas secara baik dengan hasil yang maksimal keahlian yang dimiliki seseorang dapat diperoleh dari 
pendidikan formal maupun non formal yang nantinya harus terus menerus ditingkatkan, salah satu sumber peningkatan keahlian dapat berasal dari pengalaman-pengalaman dalam bidang tertentu, (Wardani,2010) berdasarkan tulisan diatas dapat disimpulkan bahwa dengan adanya keahlian sumber daya manusia dapat meningkatkan kinerja karyawan.

\section{Pengertian Kepuasan Kerja}

Seorang karyawan akan merasa nyaman dan tinggi loyalitasnya pada perusahaan apabila memperoleh kepuasan kerja sesuai dengan apa yang diinginkan. Menurut Robbins (2003:78) kepuasan kerja adalah sikap umum terhadap pekerjaan seseorang yang menunjukkan perbedaan antara jumlah penghargaan yang diterima pekerja dan jumlah yang mereka yakini seharusnya mereka terima.Sedangkan Handoko (2000:193) menyatakan bahwa kepuasan kerja (job satisfaction) adalah keadaan emosional yang menyenangkan atau tidak menyenangkan bagaimana para karyawan memandang pekerjaan mereka.Kepuasan kerja mencerminkan perasaan seseorang terhadap pekerjaannya.

Mangkunegara (2005:117) juga mengemukakan bahwa kepuasan kerja berhubungan dengan variabel-variabel seperti turnover, tingkat absensi, umur, tingkat pekerjaan, dan ukuran organisasi perusahaan.

Kepuasan kerja berhubungan dengan turnover mengandung arti bahwa kepuasan kerja yang tinggi selalu dihubungkan dengan turnover yang rendah, dan sebaliknya jika karyawan banyak yang merasa tidak puas maka turnover karyawan tinggi.

Kepuasan memahami lingkup inisiatif dan kegiatan yang harus diurus supaya bisa menghasilkan perbedaan yang diperhatikan oleh pelanggan dan staff (Denis Walker, 2011: 11).

\section{Pengertian Kinerja}

Kinerja menurut Mangkunegara (2000) "kinerja adalah hasil kerja secara kualitas dan kuantitas yang dicapai oleh seseorang pegawai dalam melaksanakan tugasnya sesuai dengan tanggung jawab yang diberikan kepadanya."

Hasibuan

mengemukakan "kinerja (prestasi kerja) adalah suatu hasil kerja yang dicapai seseorang dalam melaksanakan tugas tugas yang dibebankan kepadanya yang didasarkan atas kecakapan, pengalaman dan kesungguhan serta waktu".

Menurut Veizal Rivai (2004) mengemukakan kinerja adalah "merupakan perilaku yang nyata yang ditampilkan setiap orang sebagai prestasi kerja yang dihasilkan oleh karyawan sesuai dengan perannya dalam perusahaan". Menurut Robert L. Mathis dan John H. Jackson Terjamahaan Jimmy Sadeli dan Bayu Prawira (2001) "menyatakan bahwa kinerja pada dasarnya adalah apa yang dilakukan atau tidak dilakukan karyawan".

\section{Kerangka Pemikiran}

Gambar 2.1 Kerangka Pemikiran

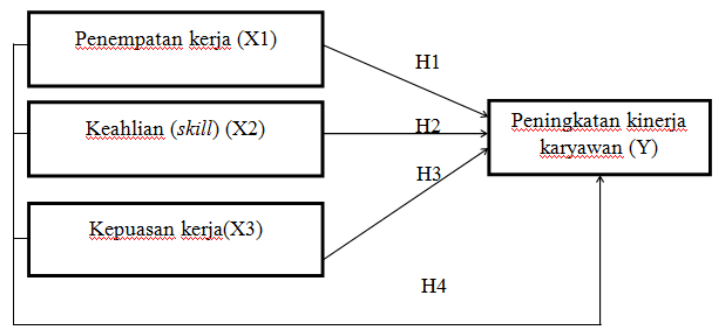

\section{Hipotesis}

$$
\text { Sumber: Respatiningsih \& sudirio ( } 2015 \text { ) }
$$

H1. Diduga bahwa penempatan kerja berpengaruh positif dan signifikan terhadap peningkatan kinerja karyaawan. 
H2. Diduga bahwa keahlian (skill) berpengaruh positif dan signifikan terhadap peningkatan kinerja karyaawan.

H3. Diduga bahwa kepuasan kerja berpengaruh positif dan signifikan terhadap peningkatan kinerja karyawan.

H4. Diduga pula bahwa penempatan kinerja, keahlian (skill) dan kepuasan kerja secara bersama-sama berpengaruh positif dan signifikan terhadap peningkatan kinerjakaryawan,

\section{METODOLOGI PENELITIAN Objek/Subjek Penelitian}

Objek

Penelitian ini menggunakan pendekatan kuantitatif dengan kategori penelitian asosiatif kausal.Pendekatan kuantitatif yang digunakan dalam penelitian ini adalah dengan menggunakan metode survei.Dalam penelitian survei, informasi dikumpulkan dari responden dengan menggunakan kuesioner.Umumnya, penelitian survei dibatasi pada penelitian yang datanya dikumpulkan dari sampel atas populasi untuk mewakili seluruh populasi. Penelitian ini bertujuan untuk mengetahui pengaruh dari variabelvariabel yang akan diteliti, yaitu pengaruh Penempatan Kerja, Keahlian ( Skill ) Dan Kepuasan Kerja Terhadap Peningkatan Kinerja Karyawan Pada PT. Osi Electronics Batam.

Subjek penelitian ini dilakukan di PT.Osi Electronics Batam berlokasi di Cammo Industri Park, Blok F No. 3a Batam Centre.

\section{Teknik Pengambilan}

Populasi menurut J. Supranto (2009:22) adalah kumpulan dari seluruh elemen sejenis tetapi dapat dibedakan satu sama lain karakteristiknya. Perbedaan perbedaan itu disebabkan karena adanya nilai karekateristik yang berlainan.Olehkarena itu Populasi penelitian ini adalah keseluhan karyawan pada PT. Osi Electronics Batam.sebanyak 124 karyawan.

Sampel adalah bagian dari jumlah dan karakteristik yang memiliki olehpopulasi tersebut (Sugiyono, 2013: 120).Dalam penelitian ini penelitimenggunakan teknik simple random sampling.Artinya responden yang dipilihsecara acak dengan karakteristik tertentu yang diyakini representative terhadap populasipenelitian.Penentuan jumlah sampel dalam penelitian ini menggunakan rumus :

$\mathrm{n}=$ Ukuran Sampel

$$
n=\frac{\mathrm{N}}{1+N e^{2}}
$$

$\mathrm{N}=$ Ukuran Populasi

$\mathrm{e}=$ Persentase ketidaktelitian karena

kesalahan pengambilan sampel

sebesar5\%

\section{Jenis Data}

1. Data Primer

Data primer dikumpukan melalui kuesioner yang dibagikan pada responden.Ini digunakan untuk meungkur penempatan, keahlian (skill), kepuasan dan peningkatan kinerja kartyawan.

2. Data Sekunder

Untuk data sekunder yang digunakan dalam penelitian ini didapat dari berbagai sumber, yaitu :

a.Jurnal merupakan artikel yang digunakan sebagai referensi penelitian ini, didapat dari jurnal-jurnal yang telah diterbitkan.

b. sumber lain yang digunakan dalam penelitian ini berupa buku, internet 
HASIL PENELITIAN DAN

PEMBAHASAN

Pengujian Data

\section{Uji Instrumentasi Penellitian}

Langkah paling penting dalam mengumpulkan data adalah melakukan pengujian terhadap instrument.Pengujian data dalam penelitian ini dilakukan dengan menggunakan Uji Validitas, Uji reliabilitas dan Uji asumsi klasik yang dilakukan serentak melalui program PSS V. 20 for Windows.Uji validitas

\begin{tabular}{|c|c|c|c|r|}
\hline & $\begin{array}{c}\text { Butir } \\
\text { Pemyataan }\end{array}$ & $\begin{array}{c}\text { Corrected } \\
\text { Item-Total } \\
\text { Correlation }\end{array}$ & r Tabel & Keteral \\
\hline Penempatan (x1) & butir1 & .702 & 0,2017 & Vali \\
\hline & butir2 & .681 & 0,2017 & Vali \\
\hline & butir3 & .623 & 0,2017 & Vali \\
\hline & butir4 & .802 & 0,2017 & Vali \\
\hline & butir5 & .606 & 0,2017 & Vali \\
\hline & butir6 & .558 & 0,2017 & Vali \\
\hline & butir7 & .577 & 0,2017 & Vali \\
\hline Kepuasan Karyawan (x2) & butir8 & .547 & 0,2017 & Vali \\
\hline & butir9 & .468 & 0,2017 & Vali \\
\hline & butir10 & .772 & 0,2017 & Vali \\
\hline & butir11 & .623 & 0,2017 & Vali \\
\hline & butir12 & .670 & 0,2017 & Vali \\
\hline & butir13 & .710 & 0,2017 & Vali \\
\hline & butir14 & .636 & 0,2017 & Vali \\
\hline
\end{tabular}

Berdasarkan Tabel 4.1 terlihat dari 3 pernyataan yang digunakan untuk mengukur variabel penempatan terlihat valid, kondisi disebabkan karena masing-masing pernyataan yang valid memiliki Coreccted Item Total Corelation diatas atau sama dengan 0,2017. Jadi dapat disimpulkan bahwa seluruh item pernyataan valid, jadi dapat terus digunakan didalam tahapan pengolahan data lebih lanjut.

\section{b. Uji Reliabilitas}

Tabel 4.5 Hasil Uji Reliabilitas

\begin{tabular}{|c|c|c|c|}
\hline Variabel & $\begin{array}{c}\text { Butir } \\
\text { Pemyataan }\end{array}$ & $\begin{array}{c}\text { Cronbach's Alpha } \\
\text { if Item Deleted }\end{array}$ & Keterangan \\
\hline Penempatan (x1) & butir1 & .909 & Reliabel \\
\hline & butir2 & .910 & Reliabel \\
\hline & butir3 & .912 & Reliabel \\
\hline & butir4 & .905 & Reliabel \\
\hline Skill (x2) & butir5 & .913 & Reliabel \\
\hline & butir6 & .914 & Reliabel \\
\hline Kepuasan Karyawan (x3) & butir7 & .914 & Reliabel \\
\hline & butir8 & .915 & Reliabel \\
\hline & butir9 & .917 & Reliabel \\
\hline & butir10 & .907 & Reliabel \\
\hline Kinerja (y) & butir11 & .912 & Reliabel \\
\hline & butir12 & .911 & Reliabel \\
\hline & butir13 & .910 & Reliabel \\
\hline & butir14 & .912 & Reliabel \\
\hline
\end{tabular}

Sumber : Hasil pengelolahan data SPSS V.20

Uji Asumsi Klasik

a. Uji Multikolinearitas

Tabel 4.6 Hasil Uji Multikolinearitas

Tabel 4.6 Hasil Uji Multikolinearitas

Coefficients ${ }^{\mathbf{a}}$

\begin{tabular}{|c|c|c|c|c|c|c|c|}
\hline \multirow{2}{*}{ Model } & \multicolumn{2}{|c|}{$\begin{array}{c}\text { Unstandardized } \\
\text { Coefficients }\end{array}$} & $\begin{array}{c}\text { Standardized } \\
\text { Coefficients }\end{array}$ & & & \multicolumn{2}{|c|}{$\begin{array}{c}\text { Collinearity } \\
\text { Statistics }\end{array}$} \\
\cline { 2 - 4 } \cline { 8 - 9 } & $\mathrm{B}$ & $\begin{array}{c}\text { Std. } \\
\text { Error }\end{array}$ & Beta & $\mathrm{t}$ & Sig. & Tolerance & VIF \\
\hline 1 (Constant) & .644 & .920 & & .700 & .486 & & \\
$\mathrm{x} 1$ & 1.068 & .096 & .679 & 11.146 & .000 & .581 & 1.722 \\
$\mathrm{x} 2$ & .146 & .138 & .083 & 1.062 & .291 & .350 & 2.854 \\
$\mathrm{x} 3$ & .435 & .108 & .267 & 4.012 & .000 & .487 & 2.054 \\
\hline
\end{tabular}

Sumber : Hasil pengelolahan data SPSS V.20

Dari tabel diatas menunjukkan bahwa nilai tolerance lebih besar dari 0,1 dan nilai VIF dari semua variabel bebas dalam penelitian ini mempunyai nilai lebih kecil dari 10 dengan demikian dapat disimpulkan bahwa tidak terdapat Multikolinearitas dalam model penelitian ini .

b. Uji Heteroskedastisitas

Gambar4.2 Uji Heteroskedastisitas 


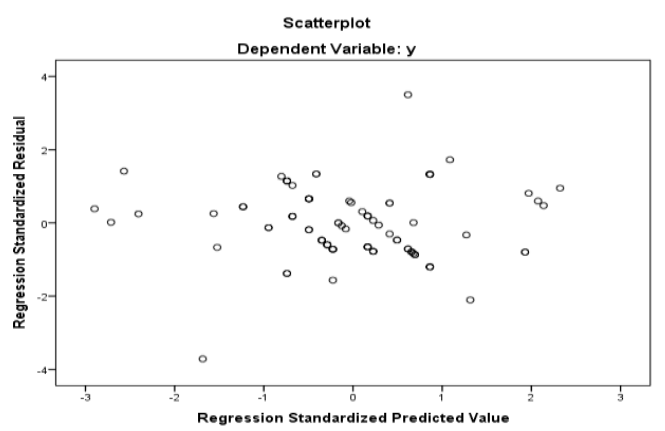

Dari grafik scatterplot tersebut terlihat titik- titik yang menyebar secara acak, tidak membentuk suatu pola tertentu yang jelas, serta tersebar baik di atas maupun dibawah angka 0 (nol) pada sumbu Y, hal ini berarti tidak terjadi penyimpangan Heteroskedastisitas pada model regresi. c. Uji Normalitas

Gambar 4.3 Uji Normalitas Histogram

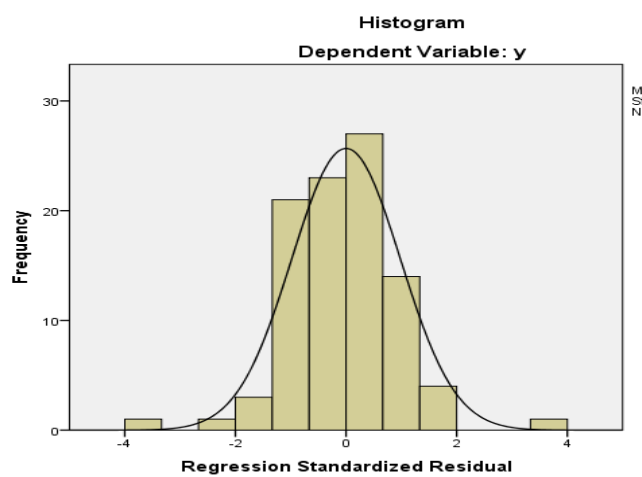

Gambar 4.4 Uji Normalitas Normal PPlot

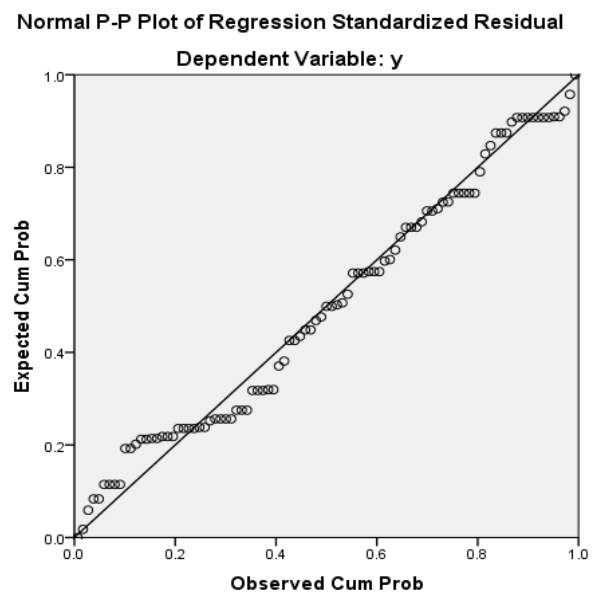

Dari gambar diatas

menunjukkan bahwa model regresi yang digunakan adalah normal. Suatu
Variabel dikatakan normal jika gambar distribusi titik- titik pada data menyebar disekitar garis diagonal, situmorang (2010).

\section{Hasil Penelitian \\ Uji Parsial (Uji t)}

Tabel 4.7 Hasil Uji T (Parsial)

\begin{tabular}{|c|l|l|l|l|l|}
\hline \multicolumn{7}{|c|}{ Coefficients $^{\mathrm{a}}$} \\
\hline \multirow{2}{*}{ Model } & \multicolumn{2}{|l|}{$\begin{array}{l}\text { Unstandardized } \\
\text { Coefficients }\end{array}$} & $\begin{array}{l}\text { Standardized } \\
\text { Coefficients }\end{array}$ & & \\
\cline { 2 - 4 } & B & Std. Error & Beta & T & Sig. \\
\hline 1 (Constant) & .644 & .920 & & .700 & .486 \\
X1 & 1.068 & .096 & .679 & 11.146 & .000 \\
X2 & .146 & .138 & .083 & 1.062 & .291 \\
X3 & .435 & .108 & .267 & 4.012 & .000 \\
\hline
\end{tabular}

Sumber: Hasil pengelolahan data SPSS V.20

Dari table di atas dapat dijelaskan :

Hipotesis 1

Varibel penempatan dengan nilai $\mathrm{t}$ hitung $11,146>\mathrm{t}$ tabel 1,662 dan tingkat signifikan 0,000 lebih kecil dari 0.05 maka Ho ditolak dan Ha diterima, artinya terdapat pengaruh yang positif dan signifikan antara penempatan terhadap kinerja.

Hipotesis 2

Variabel keahlian (skill) dengan nilai $\mathrm{t}$ hitung $1.062<\mathrm{t}$ tabel 1,662 dengan tingkat signifikan 0, 291 lebih besar dari 0,05 maka Ho di diterima dan $\mathrm{Ha}$ ditolak, artinya tidak terdapat pengaruh yang positif dan tidak signifikan antara Skill terhadap kinerja

Hipotesis 3

Variabel kepuasan dengan nilai t hitung $4,012>t$ tabel 1,662 dan tingkat signifikan 0,000 lebih kecil dari 0,05 maka Ho di tolak Ha diterima, artinya terdapat pengaruh yang positif dan Signifikan antara kepuasan karyawan terhadap kinerja 
Uji

Tabel 4.8 Hasil Perhitungan Uji F

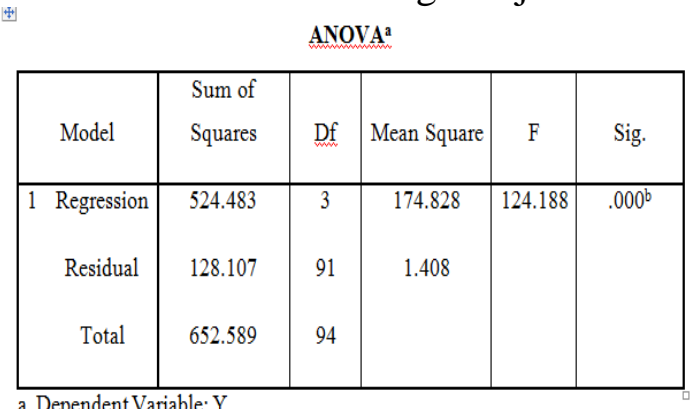

b. Predictors: (Constant), X3, X1, X2

Sumber: Hasil pengelolahan data SPSS V.20

Untuk menguji apakah model yang digunakan tempat dapat dilakukan dengan cara yaitu memandingkan Sig. pada tabel ANOVA dengan taraf nyatanya (alfa $0.05 \%$ ). Jika sig. > 0.05 maka model ditolak namun jika sig. < 0.05 maka model diterima.Pada tabel uji $\mathrm{F}$ di atas nilai sig. $<0.05$ maka dapat disimpulkan model diterima.Dari hasil analisis regresi dapat diketahui pula bahwa secara bersama-sama variabel independen memiliki pengaruh yang signifikan terhadap variabel dependen.

Hal ini dapat dibuktikan dari nilai ketahui $\mathrm{F}$ hitung sebesar $124.188>\mathrm{F}$ table 3,10 dengan tingkat signifikan 0,000 lebih kecil dari 0.05 maka kesimpulannya Ha diterima, Ho ditolak yaitu secara bersama sama antara variable $\mathrm{x} 1, \mathrm{x} 2, \mathrm{x} 3$ terdapat pengaruh yang positif dan signifikan terhadap variable $y$.

Uji Koefisien Determinasi $(\mathbf{R})^{\mathbf{2}}$ Tabel 4.9 HasilUji Koefisien Determinasi $(\mathrm{R})^{2}$

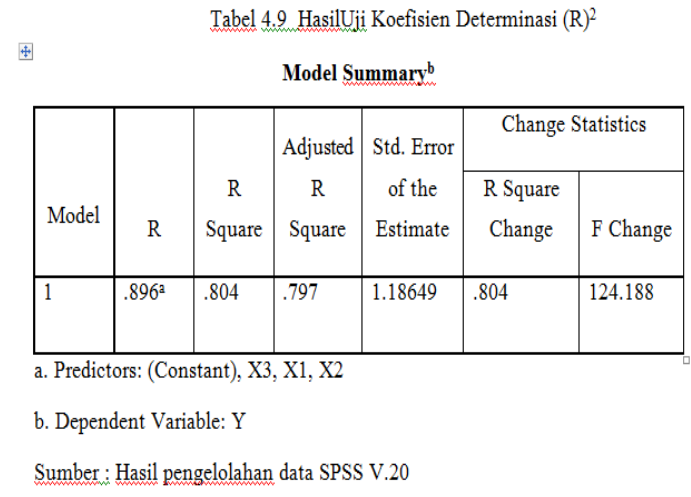

Dari hasil perhitungan SPSS, maka diperoleh nilai Adjusted R square 0,797 atau sebesar $79,7 \%$ yang artinya hubunganya kuat, kemampuan variable independent mampu menjelaskan variable dependen sebesar 79,7 \% sementara sisanya sebesar 20,3\% diterangkan oleh variable lain yang tidak termasuk didalam penelitian ini.

\section{Pembahasan}

1. Pengaruh Penempatan Kerja Terhadap Peningkatan Kinerja Karyawan

Hasil penelitian ini menunjukan bahwah penempatan kerjaberpengaruh signifikan terhadap peningkatan kinerja karyawan.Dengan demikian dapat disimpulkan bahwa H1 yaitu "penempatan kerja berpengaruh positif dan signifikan terhadap peningkatan kinerja karyawan PT. Osi Electronics Batam" diterima.Hal ini selaras dengan penelitian sebelumnya yang dilakukan oleh Evi Salwa Efendy (2017) yang menyatakan bahwa penempatan kerja berpengaruh signifikan terhadap peningkatan kinerja karyawan.

Diletakan penempatan kerja yang diberikan perusahaan maka akan semakin meningkat kinerja karyawan perusahaan. Para karyawan akan termotivasi untuk bersemangat bekerja karena diperusahaan dianggap mampu menyesuaikan penempatan kerja karyawan.Dengan meningkatnya kinerja karyawan di PT. Osi Electronics Batam.Inijuga akan meningkatkan penempatan bagi 
perusahaan tersebut karena hasil produksi akan meningkat dan kualitas produk yang baik.

2. Pengaruh Keahlian (Skill) Terhadap Peningkatan Kinerja Karyawan

Hasil penelitian ini menunjukan bahwah keahlian (skill) tidak berpengaruh signifikan terhadap peningkatan kinerja karyawan.Dengan demikian dapat disimpulkan bahwa $\mathrm{H} 2$ yaitu "keahlian (skill) tidak berpengaruh positif dan signifikan terhadap peningkatan kinerja karyawan PT. Osi Electronics Batam" ditolak. Hal ini tidak selaras dengan penelitian sebelumnya yang dilakukan oleh wahyuni (2016) yang menyatakan bahwa keahlian (skill) berpengaruh signifikan terhadap peningkatan kinerja karyawan.

Dengan menerapkan keahlian (skill) pada karyawan maka perusahaan dinilai telah mampu mesejahterakan para karyawan dan akan meningkatkan kinerja karyawan. Kinerja karyawan akan meningkat dengan meningkatnya keahlian (skill) di perusahaan.

3. Pengaruh Kepuasan Kerja
Terhadap Peningkatan Kinerja
Karyawan
Hasil penelitian ini menunjukan
bahwah kepuasan kerja berpengaruh signifikan terhadap peningkatan kinerja karyawan.Dengan demikian dapat disimpulkan bahwa $\mathrm{H} 3$ yaitu "kepuasan kerja berpengaruh positif dan signifikan terhadap peningkatan kinerja karyawan PT. Osi Electronics Batam" diterima.Hal ini selaras dengan penelitian sebelumnya yang dilakukan

\section{KESIMPULAN}

Berdasarkan hasil analisis data yang telah dilakukan dalam penelitian ini, diperoleh kesimpulan umum sebagai berikut :

1. Penempatan kerja memiliki pengaruh positif dan signifikan oleh febri furqon artadi (2015) yang menyatakan bahwa kepuasan kerjaberpengaruh signifikan terhadap peningkatan kinerja karyawan.

Dengan adanya kepuasan kerja karyawan pada perusahaan maka perusahaan dinilai telah mampu memberikan kenyamanan para karyawan dan akan meningkatkan kinerja karyawan.

4. Pengaruh Penempatan Kerja, Keahlian (Slill) Dan Kepuasan Kerja Terhadap Peningkatan Kinerja Kayawan

Hasil penelitian ini menunjukkan bahwa penempatan kerja, keahlian (slill) dan kepuasan kerja secara bersama-sama mempunyai pengaruh yang signifikan terhadap peningkatan kinerja kayawan. Hal ini dapat dilihat dari nilai $\mathrm{F}$ hitung sebesar $124.188>$ F table 3,10 dengan tingkat signifikan 0,000 lebih kecil dari 0.05 maka H4" penempatan kerja, keahlian (slill) dan kepuasan kerja terhadap peningkatan kinerja kayawan PT. Osi Electronics Batam" diterima.

Berdasarkan penelitian diatas dapat dillihat bahwa penempatan kerja, keahlian (slill) dan kepuasan kerja secara bersama-sama mempunyai pengaru yang signifikan terhadap peningkatan kinerja kayawan. Sehingga untuk meningkatkan kinerja karyawan PT. Osi Electronics Batam harus memberikan penempatan kerja, keahlian (slill) dan kepuasan kerja secara bersama-sama sehingga kinerja kayawan akan meningkat.

terhadap peningkatan kinerja karyawan PT. Osi Electronics Batam. Hal ini dapat dibuktikan dengan melihat jawaban responden yang telah diteliti yaitu dapat di kemukakan bahwa penempatan kerja dapat digunakan sebagai indikator 
peningkatan kinerja individu karyawan. Hal ini dapat dilihat dari Uji Hipotesis secara Parsial (Uji t) yaitu, nilai Sig lebih kecil dari nilai probalitas 0,05 atau nilai $0,000<0,05$ dan variabel $\mathrm{X}_{1}$ mempunayai $t_{\text {hitung }}$ $11,146>$ dari $t_{\text {tabel }} 1,662$.

2. Keahlihan (Skill) memiliki pengaruh positif dan tidak signifikan terhadap peningkatan kinerja karyawan PT. Osi Electronics Batam. Dari hasil analisis regresi dapat disimpulkan pula bahwa hipotesis kedua ditolak.Hal ini terjadi karena PT. Osi Electronics Batam menerapkan keahlian (skill) danketerampilan teknis tidak mendukung penyelesaian pekerjaan karyawan. Hal ini dapat dilihat dari Uji Hipotesis secara Parsial (Uji t) yaitu, nilai Sig lebih besar dari nilai probalitas 0,05 atau nilai $0,291>0,05$ dan variabel $\mathrm{X}_{2}$ mempunayai $\mathrm{t}_{\text {hitung }}$ $1.062<\mathrm{t}_{\text {tabel }} 1,662$.

3. Kepuasan kerja memiliki pengaruh positif dan signifikan terhadap kinerja karyawanPT. Osi Electronics Batam. Hal ini dapat dibuktikan dengan melihat jawaban responden yang telah diteliti. Hal ini dapat dilihat dari Uji Hipotesis secara Parsial (Uji t) yaitu, nilai Sig lebih kecil dari nilai probalitas 0,05 atau nilai $0,000<0,05$ dan variabel $\mathrm{X}_{3}$ mempunayai $\mathrm{t}_{\text {hitung }}$ $4,012>$ dari $t_{\text {tabel }}$ 1,662Jadi jika karyawan PT. Osi Electronics Batam terpenuhi aspek-aspek yang mempengaruhikepuasan kerja, maka kinerja karyawan akan mengalami peningkatan.
4. Penempatan kerja, keahlian ( skill ) dan kepuasan kerja secara bersama-sama berpengaaruh terhadap peningkatan kinerja karyawan pada PT. Osi

Electronics Batam. Hal ini dapat dilihat dari Uji Hipotesis secara bersama-sama (Uji F) yaitu, nilai $F_{\text {hitung }}(124.188)>$ $F_{\text {tabel }}(3,10)$ dan nilai sig < nilai probabilitas atau $0,000<0,05$.

\section{SARAN}

Berdasarkan kesimpulan yang telah dipaparkan diatas maka beberapa hal yang mungkin bisa penulis sarankan khususnya bagi PT. Osi Electronics Batamadalah :

1. Penempatan kerja merupakan suatu acuan dan sangat berpengaruh terhadap peningkatan kinerja karyawan, hendaklah pihak PT. Osi Electronics Batam. Lebih meningkatkan dan melihat penempatan yang diletakkan kepada karyawanya.

2. Keahlian (skill) masih bisa ditingkatkan dan bisa menjadi alternatife dominan yang diputuskan dan diupayakan oleh manajemen perusahaan sehingga tingkat kinerja karayawan semakin meningkat bagiPT. Osi

Electronics Batam.

3. Kepuasan juga sangat penting bagi perusahaan,karena kepuasan adalah salah satu faktor yang mempengaruhi peningkatan kinerja karyawan. Dengan adanya kepuasan individu maka perusahaan bisa melakukan beragam tugas dalam suatu pekerjaan. 
4. Pengaruh peningkatan kinerja karyawan terhadap penempatan kerja, keahlian (skill) dan kepuasan maka sebaiknya perusahaan lebih memperhatikan dan meningkatkan standar peningkatan kinerja karyawan PT. Osi Electronics Batam.sehingga tingkat kinerja karyawan semakin meningkat.

\section{DAFTAR PUSTAKA}

Ambar, Teguh Sulistiyani dan Rosidah.(2003).Sumber Daya Manusia.Yogyakarta: Graha Ilmu.

Clayton M. Charistensen. (2011). DNA Inovator-Meenguasai Keahlian Para Inovator Disruptif.Yogyakarta: CV. Andi Offset

Cushway Barry. (2002). Analisis Pengaruh Keadilan Kompensasi, Peran Kepemimpinan, Kepuasan Kerja dan Komitmen Organisasi terhadap Kinerja Karyawan Pada Sentral Pengolahan Pos Semarang.Universitas

Diponegoro, Semarang.

Handoko, H. T. (2000). Manajemen Personalia dan Sumberdaya.

Hariadja, Marihot Tua Efendi. (2005). Manajemen Sumber Daya Manusia. Jakarta: Grasindo.

Hasibuan, Malayu. (2000). Manajemen Sumber Daya Manusia, Edisi Revisi, Jakarta: PT Bumi Aksara.

Hasibuan, Malayu S.P. (2008). Manajemen Sumber Daya
Manusia. Jakarta: PT. Bumi Aksara.

Mangkunegara, A. P. (2005). Evaluasi Kinerja Sumber Daya Manusia. Bandung: Refika Aditama.

Rivai Veizal. (2004). Manajemen Sumber Daya Manusia untuk Perusahaan Dari Teori ke.Praktik. Jakarta: PT RajaGrafindo Persada.

Robbins, S. P. (2003). Perilaku Organisasi, Jilid 2. Jakarta: PT. Indeks Kelompok Gramedia.

Sadarmayanti, (2009), kinerja, sumber daya manusia.

Sulistiyani, Ambar Teguh. (2003). Jurnal Kinerja Karyawan.http://id.wikipedia.or g/wiki/Kinerja . Diakses tanggal 21 Desember 2017 jam 19.30 WIB.

Sunyoto, (2012).Analisis Pengaruh Beban Kerja Terhadap Kinerja Karyawan Divisi Marketing dan Kredit PT. WOM Finance Cabang Depok..Institut Pertanian Bogor.

Syawal, (2009).“'Soft Skillvs Hard skill .Jakarta Timur: Kantor Akuntan PublikSyarief Basir dan Rekan.

Umar, Husein. (2003). Metode Riset Bisnis. Jakarta: PT Gramedia Pustaka Utama.

Walker Denis. (2011). Mendahulukan Kepuasan

Pelanggan. Tanggerang Selatan: Binarupa Aksara Publisher. 
Wardani, Eka Suryaningsih, (2010), Pengaruh Kompensasi, Keahlian dan Motivasi Lingkungan Kerja Terhadap Prestasi Kerja Karyawan Pada PT. Pembangkitan Jawa Bali,EJurnal Manajemen, Gunadarma, Diaksespada tanggal, 21 Desember 2017 jam 19.30 WIB.

yani, (2012), placement atau penempatan, penunjukkan kepada karyawan untuk menduduki atau melakukan pekerjaan baru, Yogyakarta:CV Suka makmur 